\title{
High frequency sea level fluctuations recorded in the Black Sea since the LGM
}

\author{
G. Lericolais ${ }^{a,{ }^{*}}$, C. Bulois ${ }^{a, b}$, H. Gillet ${ }^{a, c}$ and F. Guichard ${ }^{d}$
}

a IFREMER, Centre de BREST, BP 70, F29200 Plouzané cedex, France
b UCD School of Geological Sciences, University College Dublin, Belfield, Dublin 4, Ireland
c UMR 5805 - EPOC, Université Bordeaux 1, Avenue des Facultés, F33405 Talence, France
d LSCE, CNRS-CEA, Avenue de la Terrasse, BP 1, 91198- Gif-sur-Yvette cedex, France

*: Corresponding author : G. Lericolais, email address : gilles.lericolais@ifremer.fr

\begin{abstract}
:
This paper presents a 3D geometric interpretation of very high resolution seismic Chirp profiles acquired on the Romanian shelf during ASSEMBLAGE European Project. The results provide a solid record of the Black Sea Last Glacial Maximum (LGM) water level fluctuations. This pseudo-3D seismic interpretation shows that the Black Sea lacustrine shelf deposits form a significant basinwardprograding wedge system. On top of these prograding sequences is a set of sand dunes that delineates a wave cut-terrace like feature around the isobath $-100 \mathrm{~m}$. Landward of this dune field are small depressions containing barkhan-like bodies. The upper part of the last prograding sequence is incised by anastomosed channels which end in the Danube (Viteaz) canyon which are also built on the lacustrine prograding wedge. Ten stratigraphic units were distinguished and correlated with analyses of cores retrieved from this area. The results demonstrate that the first eight sequences represent lacustrine prograding wedges, the ninth sequence is the dune system itself and the tenth is a marine mud drape which covers the entire continental shelf. The lacustrine prograding wedges represent a lowstand deposit characterised by forced regression-like reflectors mapped from the pseudo-3D seismic data. Their hinge point corresponds to the wave erosion surface mapped around - $100 \mathrm{~m}$ isobath on the multibeam mosaic. Dated cores give age control on this lowstand period, which lasted from 11 to $8.5 \mathrm{kyr}{ }^{14} \mathrm{C}$ BP as implied by: (1) the continuously dry climatic conditions in the region inferred by high percentages of herbs and steppe elements determined from ASSEMBLAGE cores and, (2) the formation of dunes between 10 and $8.5 \mathrm{kyr}{ }^{14} \mathrm{C}$ BP on the desiccated north-western Black Sea shelf at $-100 \mathrm{~m}$ and (3) all of these covered by a marine mud drape confirming that the dune system is no longer active. The buried, anastomosed fluvial channels that suddenly disappear below $90 \mathrm{~m}$ depth, and a unique wave-cut terrace between 95 and $100 \mathrm{mbsl}$ on the outer shelf are also consistent with a major lowstand base-level at around $-100 \mathrm{~m}$ water depth. Preservation of sand dunes and the occurrence of small, buried incised valleys mark a rapid transgression within less than a century during which ravinement processes related to the water level rise had no time to significantly erode the seafloor.
\end{abstract}

Keywords: sea level changes; rapid transgression; forced regression; enclosed basin; Black Sea 


\section{Introduction}

As part of its evolution, the Paratethys basin went through a small, semi-isolated basin phase at the end of the Oligocene. The link between resulting marginal basins and the ocean was episodically restricted or even severed in response to sea level changes. The Black Sea is a present-day example of such a marginal basin where the connection changes dramatically with sea level (Ross, 1971; Ross, 1978; Ross et al., 1970; Ross and Degens, 1974; Ryan et al., 2003; Ryan et al., 1997). The Black Sea is at present the world's largest anoxic basin, making it an important modern analogue for past anoxic conditions, while during the last glacial period, it was a low salinity oxygenated lake, isolated from the Mediterranean (Deuser, 1972; Deuser, 1974; Lericolais et al., 2006; Wall and Dale, 1974). The location of this inland sea, between Europe and Asia, makes its water level dependent on Eurasian climatic fluctuations. As the Black Sea has experienced a limnic situation, the deposited lake sediments are valuable archives for the study of past climate changes. During glacial periods, the ice cap prevented major rivers flowing north as they do today. Then, these rivers were diverted to the south in the direction of the Black Sea and Caspian Sea receiving basins and consequently have increased the size of these Drainage Basins (Arkhipov et al., 1995). Isolation of the Black Sea from the Global Ocean led to the establishment of unique conditions specific to the Black Sea, and avoiding the hysteresis effect which corresponds to the latent period needed by the Global Ocean to respond to the consequences of ice melting. During these isolation phases, the Black Sea was more sensitive to climate changes than the Caspian Sea is today. Some authors interpret the Caspian Sea fluctuations as opposed to those of the Global Ocean to have been caused the possible connection between the Black Sea and the Caspian Sea through the Manych Strait (Arkhipov et al., 1995; 
Chepalyga, 1984). During the glacial periods, when the Black Sea was isolated, both the lack of saltwater input and the increase of fresh water run-off from the rivers, led to reduced salinity levels in the Black Sea. This process, linked to water level fluctuation, is measured in the fauna succession showing an abrupt change from salt-to fresh/brackish-water species. However, since 1997, a still unsolved controversy concerned the last re-connection of the Black Sea to the Marmara Sea. This question is still under debate, even though each opposing view is supported with data representing only a minute part of the Black Sea floor. Yet, not all of the $420000 \mathrm{~km}^{2}$ have been surveyed using modern scientific equipment and technology to precisely understand the water level fluctuation of the Black Sea in the Quaternary. Recently, an assessment of the North-western part of the Black Sea sedimentary systems from the continental shelf and slope down to the deep-sea zone, was provided by the ASSEMBLAGE European Project (EVK3-CT2002-00090). Part of this project's deliverables consisted of applying sequence stratigraphic models to seismic data recorded on the north-western Black Sea shelf in order to correlate the sequences interpreted using seismic stratigraphy methods to sea-level fluctuations. In this paper, seismic sequences recognised on seismic profiles are interpreted in terms of systems tracts, by using the character of the erosional unconformity and of the strata truncated below it as well as the nature of the sediments above it.

To achieve these objectives, very high resolution seismic data were acquired during the BlaSON cruises (1998 and 2002) on board the research vessel "LE SUROÎT" and during the ASSEMBLAGE 2 (2004) cruise on board the research vessel "LE MARION DUFRESNE". During the early cruises paleo-shorelines and sand ridges were identified and a set of seismic data was acquired on these targets to support pseudo 3D analyses. Data Terrain Models (DTM) were made to determine the paleo-bathymetry and to establish a sequence stratigraphy model to identify age and onset of observed paleo-shorelines and ridges. Data Terrain Models also help to 
define the internal structure of these sand ridges and to decipher the nature and origin of paleovalley fills. This coupled with a multiproxy approach emphasizes that the Black Sea water level is dependent on Eurasian climatic fluctuations. This sequence stratigraphy study is validated by dated samples obtained from long cores (up to $50 \mathrm{~m}$ long) providing a firm calibration of Black Sea water level fluctuation since the LGM. It especially shows that the Black Sea experienced a contemporary rise in water level with the melting of the Fennoscandian Ice sheet followed by a drop of the water level from the Younger Dryas to the PreBoreal. This recent lowstand is confirmed by the presence of the forced regression sequences, the wave cut terrace and the coastal dunes still preserved on the shelf, even after the Black Sea was rapidly invaded by Mediterranean/Marmara marine waters.

\section{Geological setting}

\section{Black Sea Paleo-shorelines.}

Since the 1970's Russian scientists have documented Pleistocene lowstand shorelines on the north-western Black Sea shelf (Kuprin et al., 1974; Shcherbakov et al., 1978). Actually, many Soviet surveys were carried out in the Black Sea, and paleo-littoral zone near the shelf edge were identified and sampled from coring. Although these researchers had not published reflection profiles to document the exposed margin of the lake, their numerous piston and drill cores confirmed the ancient coast. Some of these cores provided evidence of an erosional surface already considered as a possible fluvial or aeolian surface (Shuisky, 1986). During this systematic exploration of the Black Sea shelf by Soviet and other eastern country researchers (Arkhipov et al., 1995; Evsylekov and Shimkus, 1995; Muratov et al., 1974; Popp, 1969; Shimkus et al., 1987; Shopov et al., 1986) paleo-incised valleys crossing the continental shelf were recognized. In the 1990's, the systematic survey of the Romanian 
shelf conducted by the GeoEcoMar Institute established the presence of ancient river valleys crossing the shelf and extensive down-cutting of the Danube (Viteaz) canyon (Lericolais et al., 2007a; Panin and Popescu, 2007; Popescu et al., 2004). This last observation leads us to propose the hypothesis of a major water-level drop of the Black Sea after the LGM and comes in supports interpretation made by Ostrovskiy et al. (1977b) and Shimkus et al. (1980) regarding the stratigraphy and geochronology of Pleistocene marine terraces recognized on the shelf break off the Caucasus and Kerch-Taman region. These authors interpreted such terraces as evidence of a water level drop of about $110 \mathrm{~m}$ linked to an iceage lowstand of the former Black Sea lake. In 1993, a new US-Russian-Turkish survey reexamined these lowstand shorelines and the river paleo-valleys of the Dniepr/Dniestr complex in more detail using very high resolution seismic reflection profiling methods and observed lowstand terraces (Major et al., 2002a; Ryan et al., 1997). Similar terraces have also been recognized on the Bulgarian shelf (Dimitrov, 1982; Genov, 2004) and on the northern Turkish shelf (Aksu et al., 2002b; Algan et al., 2007; Algan et al., 2002; Ballard et al., 2000; Demirbag et al., 1999; Okyar et al., 1994). Among these terraces, shells belonging to past coastal environments were dated between 19 to 9 kyr BP (Dimitrov, 1982; Lericolais et al., 2006; Ostrovskiy et al., 1977a; Shcherbakov et al., 1978). On the Romanian continental shelf, Popescu et al. (2004) noticed the absence of incised river channels below 90 m water depth where a wave-cut terrace-like morphology was mapped about $100 \mathrm{~km}$ from the Danube delta. These wave-cut terraces were interpreted to be erosional surfaces created by erosion from wave action indicating the position of the shoreline (Lericolais et al., 2007a; Lericolais et al., 2007b). Since rivers do not always generate continuous incised valleys along the shelf (Lericolais et al., 2001; Talling, 2000; Wescott, 1993), their absence below isobath $-90 \mathrm{~m}$ does not necessarily indicate the location of the paleo-coastline. A 
good indicator of the paleo-coastline is the wave-cut terrace around the head of the Danube (Viteaz) canyon and present between isobath -98 m and isobath -112 m (Popescu et al., 2004). North of the Danube (Viteaz) Canyon, the terrace deepens again to -97 $\mathrm{m}$ while the height increases to $10-15 \mathrm{~m}$, and splits into two distinct steps. The last lowstand paleocoastline should thus have been situated between this submerged terrace and the deepest buried fluvial channels (Lericolais et al., 2007a). All subsequent seismic reflection profiling acquired (e. g. BlaSON and ASSEMBLAGE surveys) show the same shelf-wide erosion surface (Gillet et al., 2003; Lericolais et al., 2007a; Lericolais et al., 2007b; Popescu et al., 2004).

\section{Black Sea water level fluctuations}

Before todays controversy concerning the Black Sea water level fluctuation since the Last Glacial Maximum, the consensus was that the Black Sea lake's surface had risen in pace with global sea level, assuming that the connection between Mediterranean and Black Sea waters was already possible through an early existing Bosporus Strait. The increase in salinity in the Sea of Marmara is known to be at least 12000 years BP as determined from the mollusc assemblage and stable isotopes (Cagatay et al., 2000; Sperling et al., 2003) and could be even earlier (Popescu, 2004; Popescu et al., 2003). In 1997, based on results obtained from a joint Russian-American-Turkish expedition carried out in 1993, Ryan et al. (1997) provided evidence in support of a catastrophic flood of the Black Sea 7500 years ago. Their interpretation was deduced from high-resolution seismic reflection profiles and carbon-14 Accelerator Mass Spectrometry (AMS) dating of fauna sampled from cores targeted on these profiles. In 2002, Aksu et al. (2002a) presented arguments for persistent Holocene outflow from the Black Sea to the eastern Mediterranean and for non-catastrophic 
variations in the Black Sea water level over the last 10000 yr BP (Aksu et al., 2002b). Recently Yanko-Hombach et al. (2007b) published a book entitled "The Black Sea Flood Question; Changes in Coastline, Climate and Human Settlement" trying to address issues of geological evolution and human adaptation in the Circum-Pontic region during the Late Pleistocene and Holocene. Among the contributors of this book are many Eastern European scientists whose work has rarely been published in any language but Cyrillic. Each of the papers in the book has arranged its evidence for or against the flood hypotheses. Nevertheless, recent publications on the subject provide confusion between AMS uncorrected ages and calendar ages (Yanko-Hombach et al., 2007a) which represent an important issue for the Black Sea. Reservoir age is estimated at some $415 \pm 90$ yr BP by Siani (Siani et al., 2000), Guichard et al. (1993) have proposed an average age reservoir of 1 $280 \mathrm{yr}$ based on tephra from the Minoan event recovered in the Black Sea and more recently a reservoir age of more than $1000 \mathrm{yr}$ is suggested (Bahr et al., 2006; Kwiecien et al., 2006). It would now appear, that it is necessary to apply a reservoir age correction of about $1200 \mathrm{yr}$ to limnic Black Sea sediments and an average of $400 \mathrm{yr}$ after the reconnection. Still in this book, some physical incoherency can be also pointed out, such as Balabanov (Balabanov, 2007) for instance, who considers a specific Black sea level fluctuation after 8000 yrs BP never described in the Mediterranean whereas the two seas were reconnected, leading Giosan (2007) to write with sense: "Taking into account that the Black Sea was connected with the World Ocean all this time demonstrating that these regressions were real would turn all we know about the Holocene sea level in the ocean on its head". Authors who are against a late connection of the Black Sea to the Mediterranean sea are now publishing evidence of a late salinisation of the Black Sea obtained from their studies conducted on cores recovered on the Black Sea Turkish shelf, i.e. Hiscott et al. 
(2007) explains that the Ostracoda of Caspian affinity indicate 5\%o salinity until 7.5 ka. Dinocysts and foraminifera confirm a low but rising salinity no later than $~ 8.6 \mathrm{ka}$ and a first major pulse of marine waters is recorded at around 8.46 ka BP by Marret et al. (Marret et al., 2007). They propose a complicated explanation to refute a late reconnection as evidenced by relics coastal dunes and wave cut terraces. This is consistent with the results obtained by Maheim and Chan (1975) who suggest that during isolation of the Black Sea during the LGM (Neoeuxinian), there was a relatively homogeneous chlorinity of about $3.5 \mathrm{~g} / \mathrm{kg}$, compared with more than $12 \mathrm{~g} / \mathrm{kg}$ in present bottom water.

\section{Rapid Transgression}

Other important facts in favour of a rapid transgression in the Black Sea is supported by Khrischev and Georgiev (1991), Lericolais et al. (2004; 2003). Khrischev and Georgiev (1991) attribute "fast rising" water level to the transition from lacustrine to marine conditions. For them, this change corresponds to a stratigraphic break ("washout") in the cores that interrupts the lacustrine calcite precipitation and is followed by terrigenous mud with marine molluscs. They report this "washout" in more than 100 cores. This same transition was described for the BlaSON and ASSEMBLAGE cores, but here the transition was interpreted as an erosion surface (Lericolais et al., 2007a; Lericolais et al., 2007b; Major et al., 2002b). Calvert (1990), Calvert and Fontugne (1987), Lane-Serff et al. (1997) interpreted this discontinuity as a freshwater flushing leading to a mechanism that lifts nutrients to the surface enhancing productivity and eventually causing anoxia and sapropel deposition. There is a thin layer of precipitated aragonite at the sapropel base (Degens and Ross, 1972; Giunta et al., 2007; Jermannaud, 2004; Jones and Gagnon, 1994; Major et al., 
2006) that forms in calcite-saturated lake environments into which there is an introduction of marine sulphate.

Additionally, as described by Wong et al. (2005) and by Algan et al. (2002) and Lericolais et al. (2007a; 2007b), a uniform mud drape is deposited above the unconformity along the Black Sea margin. This mud drape layer was sampled during BlaSON and ASSEMBLAGE and corresponds in cores to the layer of terrigenous mud containing marine molluscs such as Mytilus galloprovincialis and edulis, Cerastoderma edule and Cardium edule (Lericolais et al., 2005). This lithologic and biostratigraphic interval on the shelf corresponds to Units 1 and 2 in basin sediments as defined by (Ross et al., 1970).

\section{Pseudo 3D Methodology}

ASSEMBLAGE very-high-resolution seismic data was acquired with sub-meter resolution and penetration of a few meters to several tens of meters. Representative areas were selected to apply specific seismic data processing in order to build data terrain models (DTM), to determine the paleo-bathymetry and to establish a sequence stratigraphic framework. Pseudo 3D seismic interpretation has allowed us to identify paleo-shorelines, prograding features, and indicators of water level fluctuation.

\section{Data Set}

The geophysical data were acquired during three cruises conducted from 1998 to 2004 with the research vessels "Le Suroit" and "Le MARion Dufresne" (Figure 1). A Differential GPS system was deployed for accurate (about $1 \mathrm{~m}$ ) positioning. 
The main very high resolution seismic sources were Chirp sonars (Xstar and Ixsea hull mounted) with frequencies varying between 1.5 and $7 \mathrm{kHz}$. A total of more than $10000 \mathrm{~km}$ of very high resolution and high quality profiles were recorded both in analogue and digital modes. Their vertical resolution is less than $1 \mathrm{~m}$ with a penetration reaching $500 \mathrm{~ms}$ in some deep areas where the sediment cover is soft. On the shelf, the presence of high gas bearing sediments (to about $20 \mathrm{~m}$ depth in the sediment column) masks the data below and decreases the amount of usable data. Two dense pseudo-3D seismic grids have been acquired on the shelf covering a total area of 20 by $5 \mathrm{~km}$, with spacing between track lines of $500 \mathrm{~m}$.

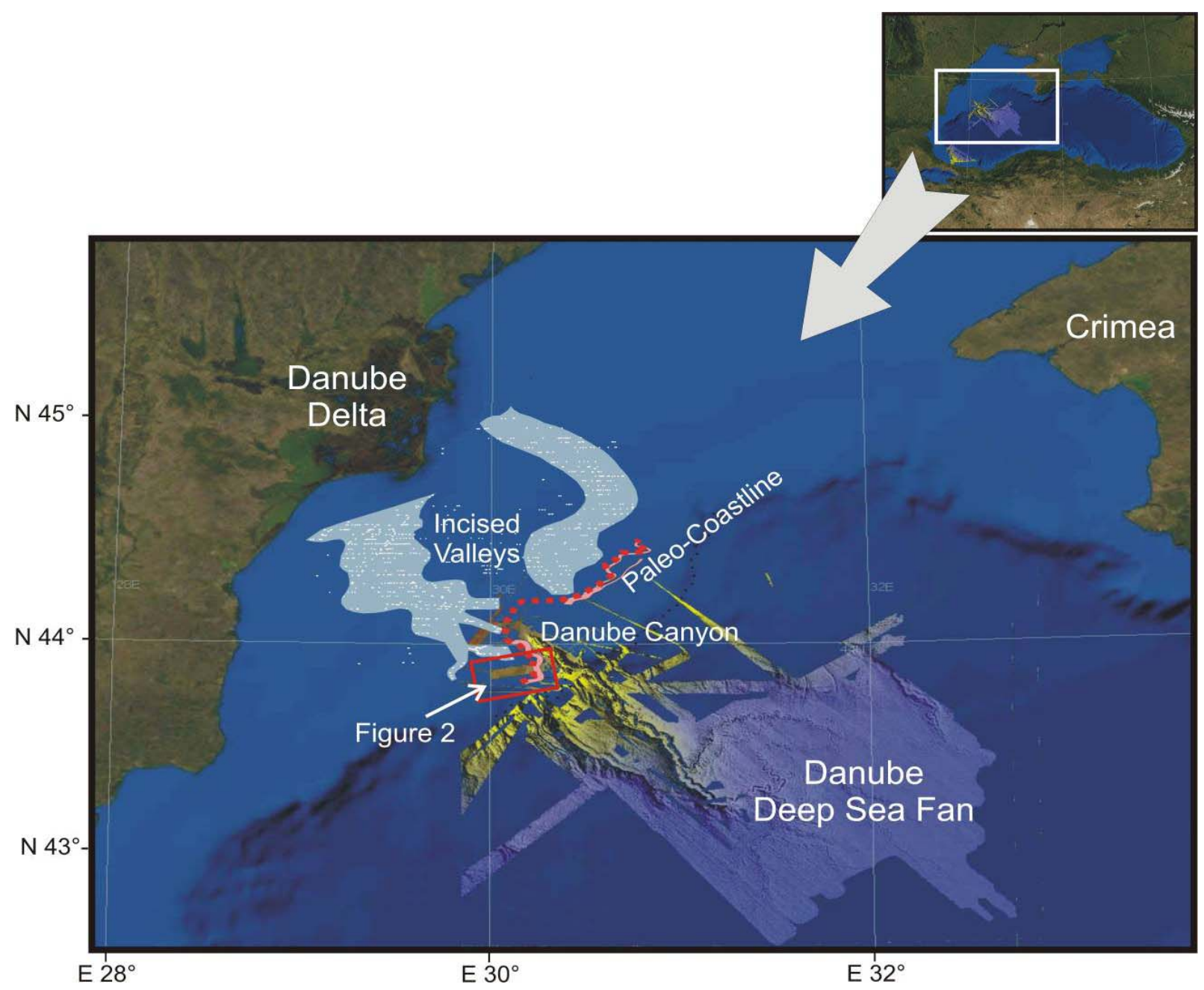

Figure 1: Paleogeographic map of the north-western Black Sea margin. Individual incised paleo channels identified on shallow seismic profiles were shot by the GeoEcoMar Institute and interpreted by Popescu et al. (2004). Areas characterized by dense occurrence of buried channels cluster in two main paleo-drainage systems. 
Analysis of the Chirp data is based on two distinct steps: a seismic data processing phase using software dedicated to the processing of very high resolution seismic: SISBISE developed by Hervé Nouzé on the basis of the former SITHERE software (Lericolais et al., 1990; Nouzé, 1993). The conventional processing flow applied included pass-band filtering, bottom multiple attenuation and signal envelope amplification. From this processing, seismic line plots were printed and Seg-Y format files were created. Then seismic files in Seg-Y format and original navigation files were imported in the Kingdom Suite software. This first step was followed by interpretation of the seismic line and computing of isochron maps using Kingdom Suite software (Seismic Micro-Technology, Inc.).

\section{Seismic stratigraphy}

Analysis of these seismic data followed a classic procedure based on the analysis of the reflection terminations (erosional truncation, onlap, downlap) and geometry. It allowed the identification of the seismic units and their boundaries (Mitchum et al., 1977). Using the principles seismic units were defined according to the reflection configurations, seismic facies identification and association, and geometric analysis. Ten major units were picked on the Chirp seismic profiles based on these criteria. Reflector depths were checked at all tie-points and digitized interactively on digital profiles with 'Kingdom Suite' software.

\section{Seismic Data Terrain Models}

The Kingdom Suite (Seismic Micro-Technology, Inc.) is an industry leading seismic interpretation software package. Digitalization of the seismic stratigraphic interpretation imported into Kingdom Suite allowed us to create isochron maps of the identified seismic 
units. Corresponding grids and contour maps were computed by mean of the "gradient projection" gridding algorithm.

\section{Results and Sedimentological Interpretation}

\section{Localization of the selected area}

The area of interest was chosen from the area where a high density of seismic profiles were acquired to realize the DTM and where a bathymetric study is available (Lericolais et al., 2007a) (Figure 2). In the north-eastern part of this mosaic, linear ridges 4 to $5 \mathrm{~m}$ in relief and with an average spacing of $250 \mathrm{~m}$ are prominent. They strike almost uniformly obliquely to a berm-like step along a north-south axis of the mosaic. In addition, depressions with diameter from 100 to $500 \mathrm{~m}$ and negative relief of 5 to $10 \mathrm{~m}$ are present in the south-western half of the corridor. The wave-cut terrace described as unique on the outer shelf by previous workers (Lericolais et al., 2007a; Lericolais et al., 2007b; Major et al., 2002b; Popescu et al., 2004; Ryan et al., 2003) is clearly evident on the presented mosaic. The upper surface of the berm varies around $-90 \mathrm{~m}$. 


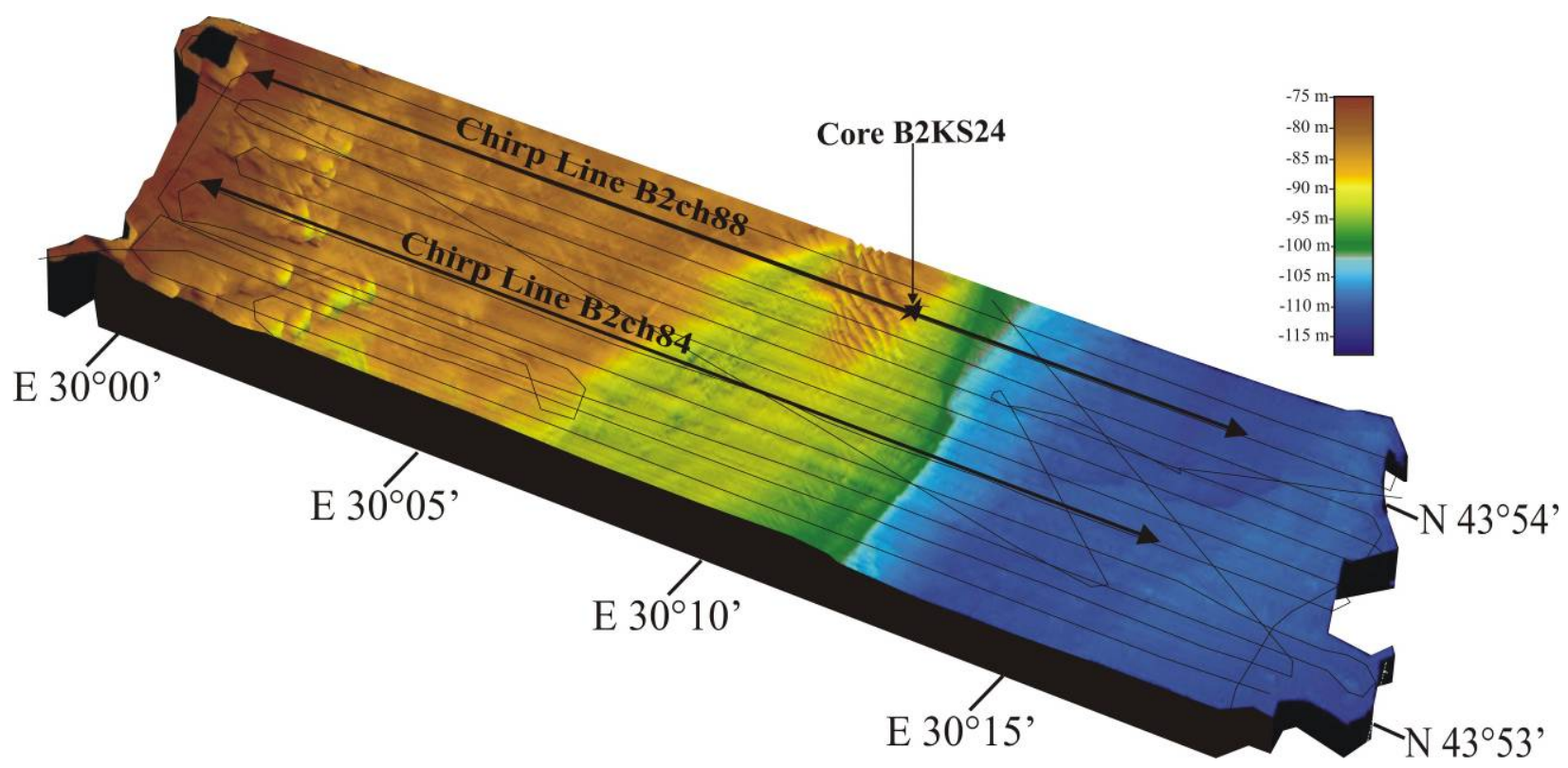

Figure 2: Seismic profiles interpreted to realize the DTM located on the multibeam mosaic (Lericolais et al., 2007a). Profiles B2ch84 and B2ch88 are used in this paper.

\section{Identification of major seismic sequences}

Ten seismic units were identified on the seismic profiles (Figure 3). Two examples among the 18 profiles used to realize the DTM are presented Figures 4 and 5. The seismic units are numbered from $\boldsymbol{S}_{\boldsymbol{I}}$ to $\boldsymbol{S}_{\boldsymbol{X}}$ ranging from the oldest to the youngest. As mentioned before, these units were distinguished using a classic procedure based on the analysis of the reflection terminations (erosional truncation, onlap, downlap) and of reflection configuration (i.e. acoustic facies), in order to identify the boundaries of the seismic units. They were also correlated with cores recovered in the area. From the core analysis, we can distinguish 3 types of depositional environments: a marine unit restricted to the $\boldsymbol{S}_{\boldsymbol{X}}$ unit, the dune foreset unit $\boldsymbol{S}_{I X}$ and the lacustrine environment $\left(\boldsymbol{S}_{V I I I}\right.$ to $\left.\boldsymbol{S}_{\boldsymbol{I}}\right)$. Figure 3 gives the general stratigraphic succession which was used throughout the study. Figures 4 and 5 are two characteristic profiles with the different units picked for interpretation. 


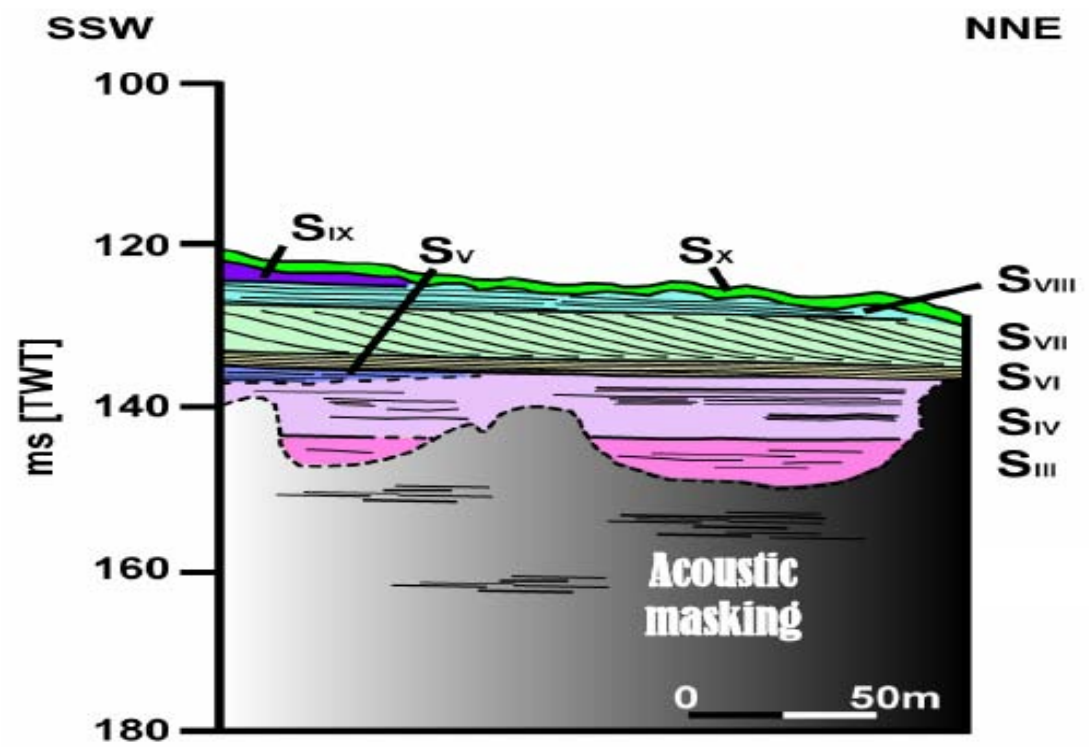

Figure 3: Schematic stratigraphic log of the 10 sequences interpreted on the dune field mosaic.

$S_{X}$ is a marine unit corresponding to the mud drape initially described by Ryan et al. (Ryan et al., 1997), $S_{I X}$ for the dune unit and $S_{V I I}$ to $S_{I}$ to the lacustrine environment. 


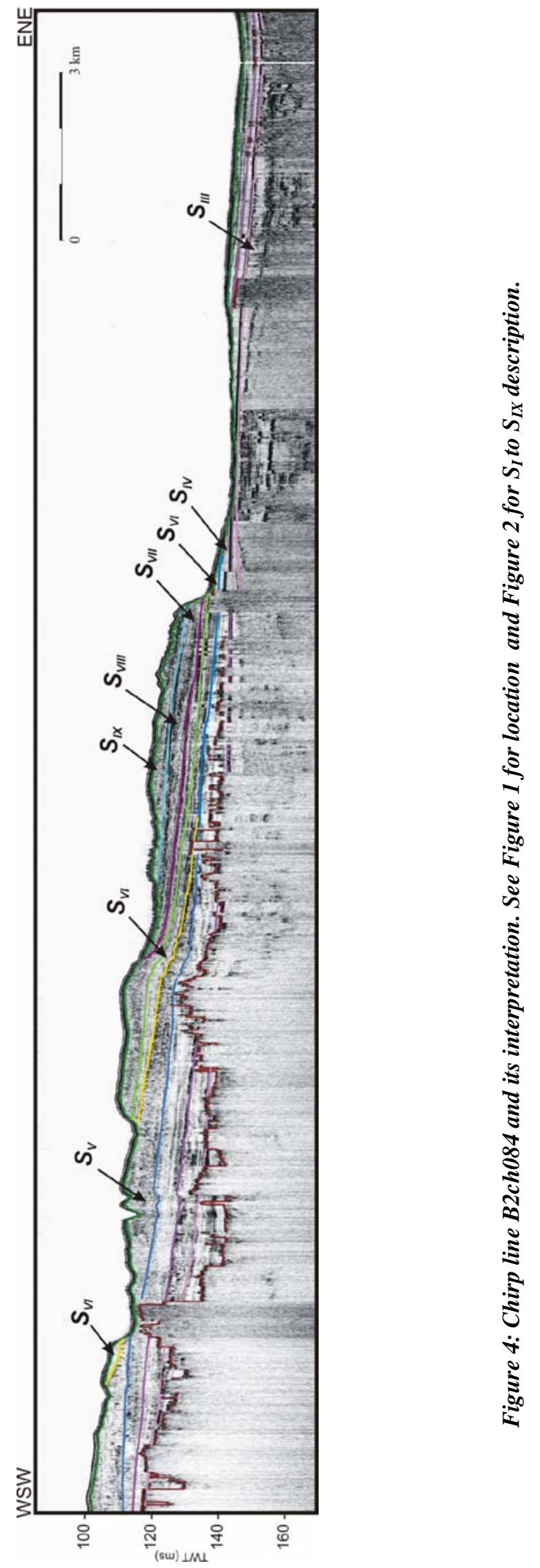




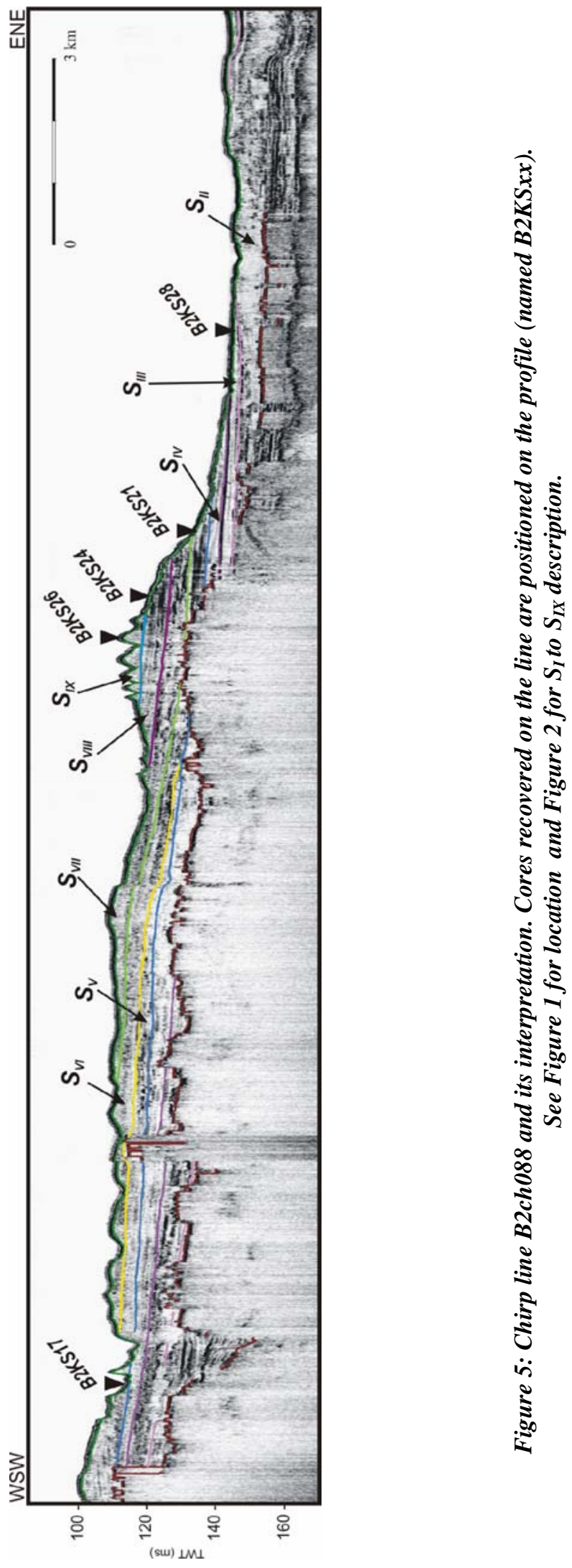




\section{Information on the sequences from core lithology}

The nature and environment of the sequences interpreted on the seismic profiles and information on their ages were deduced from the analysis of the cores recovered in the area. For instance, Figure 6 presents the results obtained from core B2KS24 recovered on the profile B2ch88 (see Figure 1. for location).

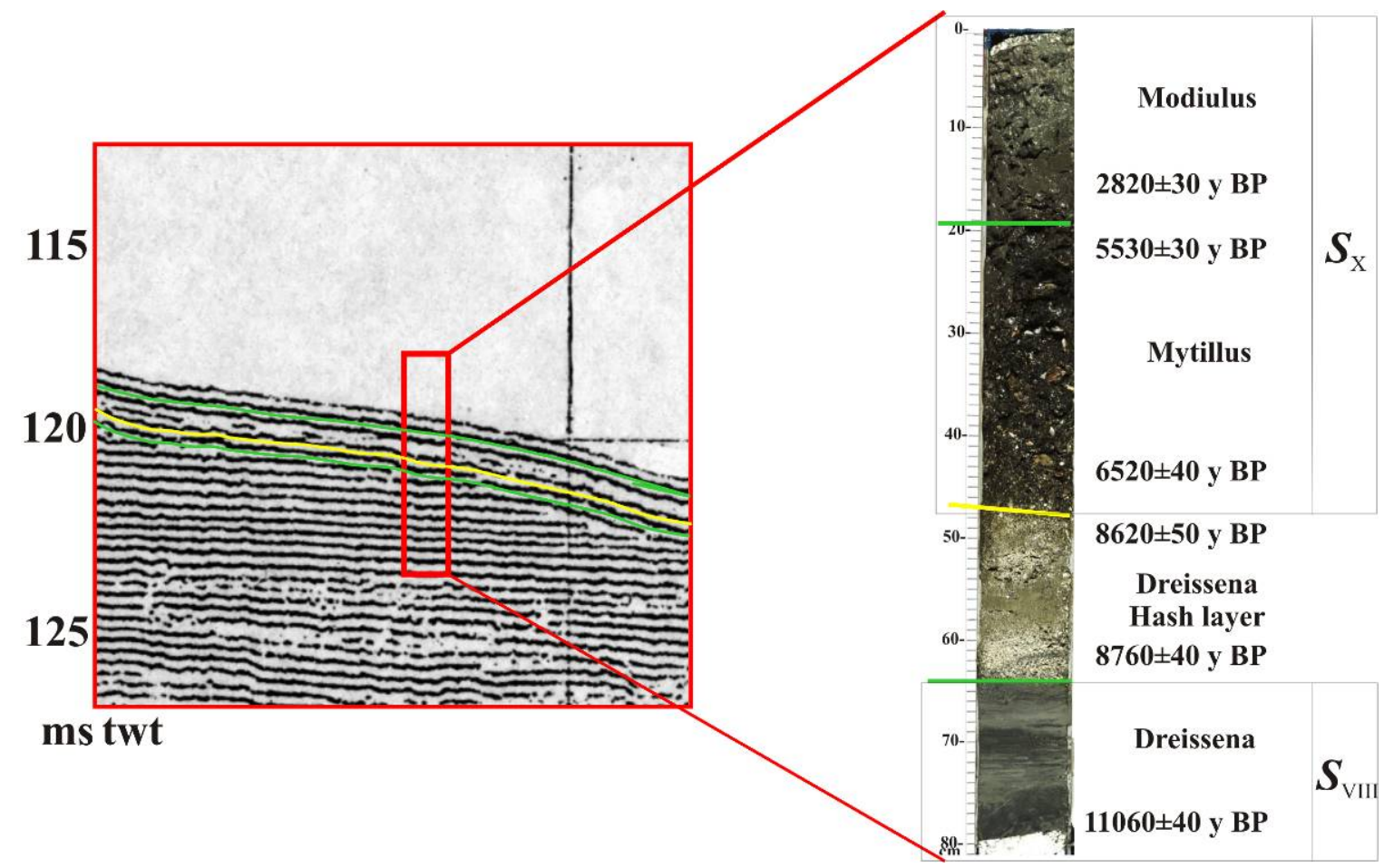

Figure 6: Age and character of the last seismic sequences $S_{V I I I}$ (limnic sediments) and $S_{X}$ (marine sediments.

A substantial number of Accelerator Mass Spectrometer (AMS) ${ }^{14} \mathrm{C}$ dates were obtained from BlaSON and ASSEMBLAGE cores. They made possible the assembly of a useful Black Sea lithostratigraphic chronology reaching back to $26,000 \mathrm{yr}{ }^{14} \mathrm{C}$ BP. Our ${ }^{14} \mathrm{C}$ dating, ages as presented here are in raw carbon 14 years before 1950 and these dates are neither corrected for reservoir age nor calibrated to tree rings. By using raw values, comparisons can be made with ${ }^{14} \mathrm{C}$ dates published long before corrections and calibrations were applied. 
Furthermore, we do not have direct knowledge of reservoir ages ( $\sim 60$ yrs as given by Jones and Gagnon (1994), 400 yrs by Siani et al. (2000), 1280 yrs by Guichard et al. (Guichard et al., 1993) and more than 1000 yrs for Bahr et al. (Bahr et al., 2006) to 1400 yrs for Kwiecien et al. (Kwiecien et al., 2006). In such a case any premature reservoir age correction may be so invalid. The dates used to correlate the different stratigraphic units interpreted in this study are displayed in Table 1.

Location of some of the cores recovered and used for this study are located on the Chirp line B2CH88 (Figure 5). All core positions are presented on Figure 8.

\begin{tabular}{|c|c|c|c|c|c|c|}
\hline Unit & Core & Depth in core & $\begin{array}{l}\text { Water } \\
\text { Depth } \\
\end{array}$ & Material & Dates (yr ${ }^{14} \mathrm{C}$ BP) & Dated Material \\
\hline$S_{X}$ & All cores & $<50 \mathrm{~cm}$ & & Mud & $<6900$ & Mytillus \\
\hline$S_{I X}$ & B2KS24 & $51-53 \mathrm{~cm}$ & $96 \mathrm{~m}$ & $\begin{array}{c}\text { Silt/sand } \\
\text { (Dune foresets) }\end{array}$ & $8620 \pm 50$ & Dreissena \\
\hline$S_{\text {VIII }}$ & $\begin{array}{l}\text { B2KS24 } \\
\text { B2KS21 }\end{array}$ & $\begin{array}{l}60-62 \mathrm{~cm} \\
41-43 \mathrm{~cm}\end{array}$ & $\begin{array}{l}96 \mathrm{~m} \\
112 \mathrm{~m}\end{array}$ & Silty clay & $\begin{array}{l}8760 \pm 40 \\
8600 \pm 50\end{array}$ & Dreissena \\
\hline$S_{V I I}$ & $\begin{array}{l}\text { B2KS24 } \\
\text { B2KS24 } \\
\text { B2KS24 }\end{array}$ & $\begin{array}{l}110-111 \mathrm{~m} \\
133-134 \mathrm{~m} \\
134-135 \mathrm{~m}\end{array}$ & $96 \mathrm{~m}$ & Silty grey clay & $\begin{array}{l}11040 \pm 50 \\
10930 \pm 50 \\
11090 \pm 50\end{array}$ & Dreissena \\
\hline$S_{V I}$ & Not cored & Not sampled & & & & \\
\hline$S_{V}$ & B2KS17 & & $88 \mathrm{~m}$ & & & \\
\hline$S_{I V}$ & B2KS21 & Not sampled & & & & \\
\hline$S_{I I I}$ & B2KS28 & $34-36 \mathrm{~cm}$ & $112 \mathrm{~m}$ & Grey clay & $10100 \pm 50$ & Dreissena \\
\hline$S_{I I}$ & BLKS9832 & $88.5 \mathrm{~cm}$ & $75 \mathrm{~m}$ & Rock & $\begin{array}{c}\text { Erosion; ravinement } \\
\text { surface ? }\end{array}$ & \\
\hline$S_{I}$ & $\begin{array}{l}\text { BLKS9830 } \\
\text { BLKS9834 } \\
\text { BLKS9834 }\end{array}$ & $\begin{array}{c}52 \mathrm{~cm} \\
60 \mathrm{~cm} \\
235 \mathrm{~cm}\end{array}$ & $\begin{array}{l}70 \mathrm{~m} \\
76 \mathrm{~m} \\
76 \mathrm{~m}\end{array}$ & $\begin{array}{l}\text { Stiff mud/delta } \\
\text { Stiff mud/delta } \\
\text { Stiff mud/delta }\end{array}$ & $\begin{array}{l}23630 \pm 180 \\
24980 \pm 200 \\
26630 \pm 230\end{array}$ & $\begin{array}{l}\text { Bulk organic C } \\
\text { Bulk organic C } \\
\text { Bulk organic C }\end{array}$ \\
\hline
\end{tabular}

Table 1: AMS ${ }^{14} \mathrm{C}$ Dates obtained from cores recovered on the studied area and reaching the different units analyzed. 


\section{Pseudo 3D sequence time-slices}

All time slices are presented in Figure 7. They represent the morphology of each interpreted unit. The top of unit $10\left(\boldsymbol{S}_{\boldsymbol{X}}\right)$ corresponds to the present bathymetry (Figure 2). The top of unit $9\left(\boldsymbol{S}_{\boldsymbol{I X}}\right)$ corresponds to the winnowed and reworked unit, referred to here as the "shell hash layer", marking subaerial reworking, erosion, and abrasion having produced the shell hash layer. The top of unit $8\left(\boldsymbol{S}_{V I I I}\right)$ corresponds to the base of the sand dune foreset beds. These three last units $\boldsymbol{S}_{\boldsymbol{X}}, \boldsymbol{S}_{I X}$ and $\boldsymbol{S}_{\boldsymbol{V I I I}}$ are not indicative of the paleomorphology of the system and so, are not represented on the time slices. The forced regression succession is represented by the prograding sequences mapped here from the top of unit III $\left(\boldsymbol{S}_{I I I}\right)$ to the top of unit VII ( $\left.\boldsymbol{S}_{V I I}\right)$. This prograding succession sits above unit II $\left(\boldsymbol{S}_{I I}\right)$ from which cores have shown some indication of ravinement probably corresponding to the upper limit of the melt water pulse transgression. Dates obtained for unit $\boldsymbol{S}_{\boldsymbol{I}}$ (Table 1) demonstrate that this unit is the distal part of the lowstand paleo-delta and paleo-prodelta system set up at the head of the Danube canyon. The geomorphologic distribution of the lacustrine like sequences is represented on Figure 8. 

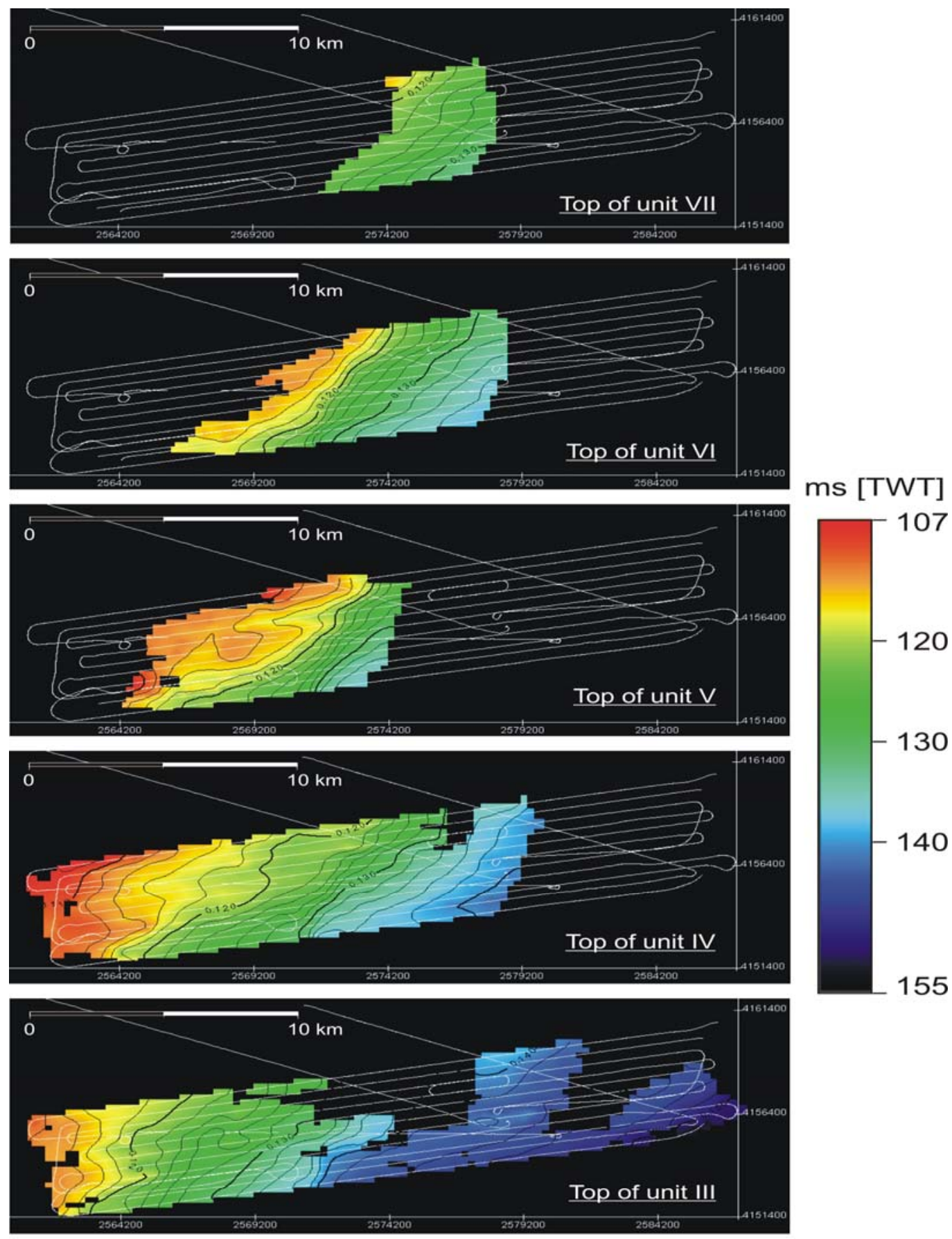

Top of unit IV
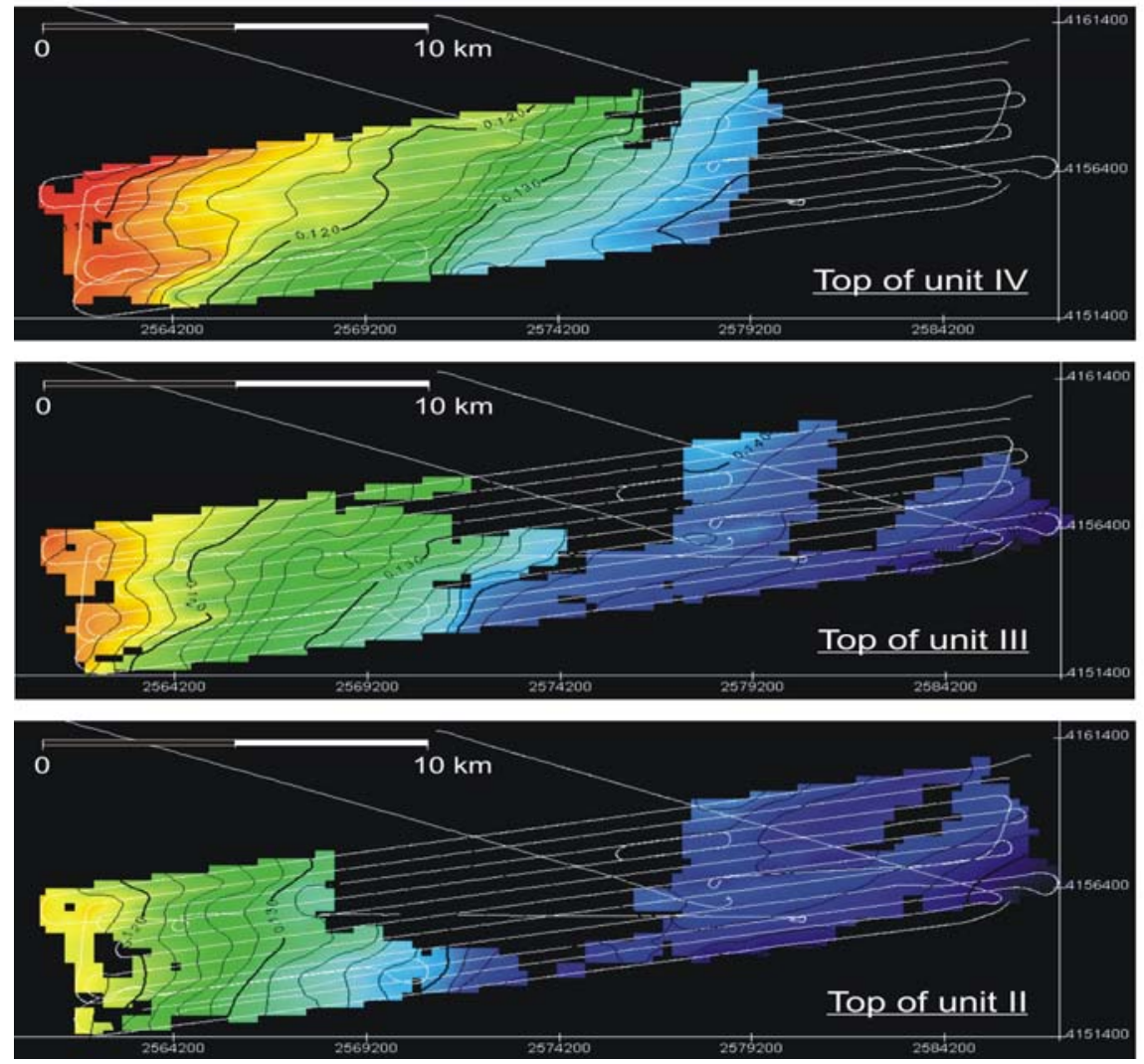

Figure 7 - Time slice of the interpreted units. Since unit IV the seaward prograding character of the units is well marked. 


\section{Discussions}

The analysis of the very high-resolution seismic data in pseudo3D mode demonstrates that the last climate change known during Holocene times was well recorded in the Black Sea basin. A particularly good record is the water level fluctuations of the Black Sea itself.

The 3D geometric interpretation of Chirp profiles acquired on the Romanian shelf shows that the lacustrine shelf deposits form an important basinward-prograding wedge system. On top of these prograding units is a set of sand dunes that delineates a berm-like feature around the -100 m isobath. Landward of this dune field are small depressions containing Barkhan-like features. The upper part of the last prograding unit is incised by anastomosing channels which end in the Danube canyon (Lericolais et al., 2007a; Popescu et al., 2004). This incision phase and the dunes are built on the lacustrine prograding wedge. Ten units were picked using the seismic sections acquired during the BlaSON and ASSEMBLAGE cruises. Analyses of cores retrieved from this studied area demonstrate that the first eight units represent lacustrine prograding wedges, the ninth unit is the dune system itself and the tenth is a marine mud drape. The lacustrine prograding wedges document a low water level characterised by forced regression-like reflectors mapped from the pseudo-3D seismic data. Their hinge point corresponds to the wave erosion surface mapped around the $-100 \mathrm{~m}$ isobath on the multibeam mosaic. Dated cores recovered in the area give age control on this lowstand period, which lasted from 11 to $8 \mathrm{kyr}{ }^{14} \mathrm{C}$ BP as implied by: (1) the continuously dry climatic conditions in the region inferred from high percentages of herbs and steppe elements determined from the ASSEMBLAGE cores (Popescu, 2004); and (2) the formation of dunes between around $8.5 \mathrm{kyr}{ }^{14} \mathrm{C}$ BP on the desiccated north-western Black Sea shelf at $100 \mathrm{~m}$ below the Black Sea present sea level. 


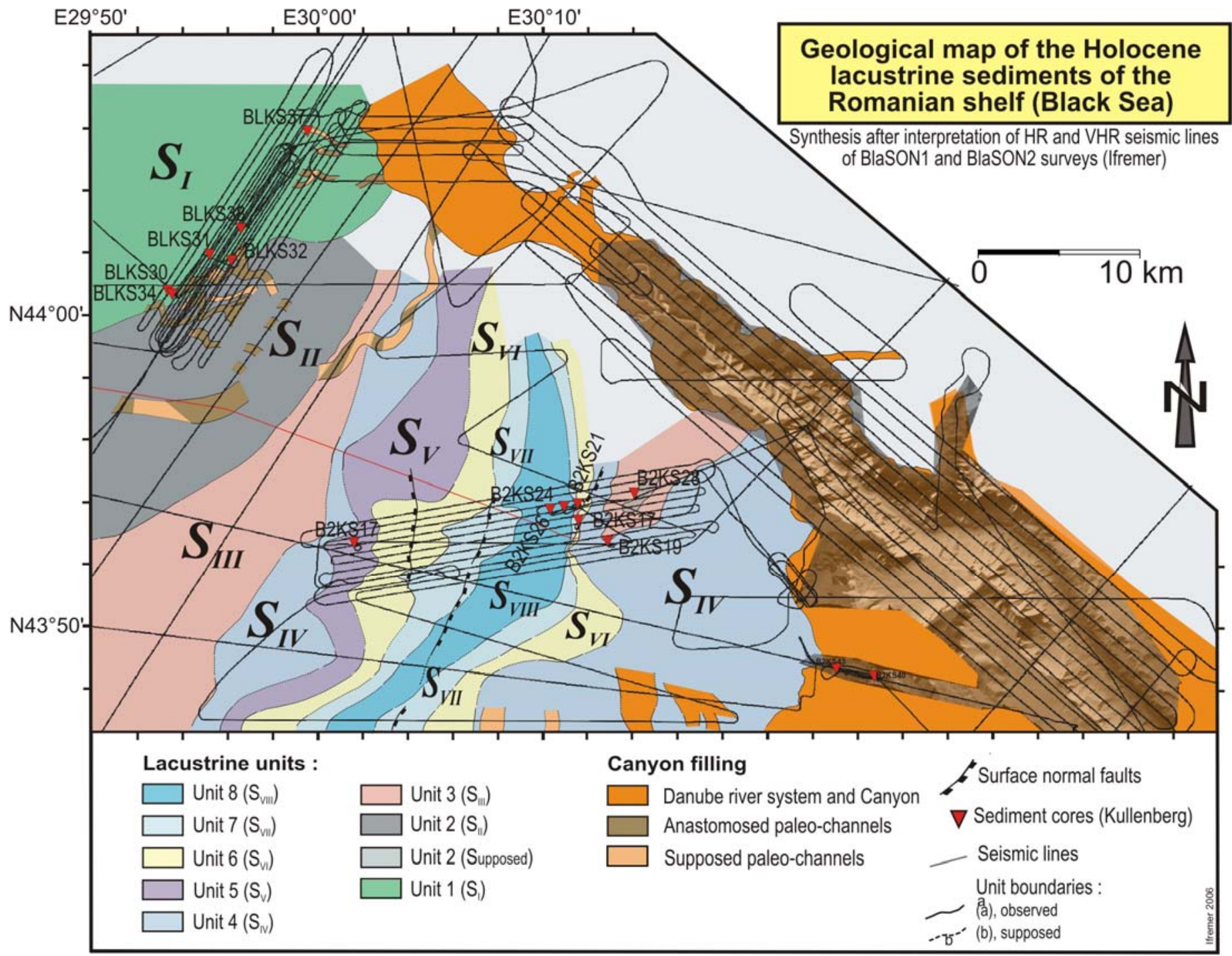

Figure 8 - Geological map of the Holocene lacustrine sediments of the Romanian shelf in the vicinity of the Danube Canyon. This synthesis was realized from the interpretation of HR and VHR seismic lines of BlaSON1 and BlaSON2 surveys. 
Similar observations and interpretation have been made by numerous Russian authors suggesting, a Black Sea level lowstand at about $-90 \mathrm{~m}$ based on the location of offshore sand ridges at the shelf-edge south of the Crimea Peninsula (Aybulatov and Shcherbakov, 1990; Fedorov, 1963; Fedorov, 1972; Fedorov, 1988; Kuprin et al., 1974; Muratov et al., 1974; Neprochnov, 1980; Nevesskaja and Nevesskiy, 1961; Shcherbakov and Babak, 1979; Shcherbakov et al., 1980; Shimkus et al., 1987). The buried, anastomosing fluvial channels (Popescu et al., 2004) that abruptly disappears below $-90 \mathrm{~m}$ depth, and a unique wave-cut terrace between -95 and $-100 \mathrm{~m}$ on the outer shelf are therefore consistent with a major level lowstand at somewhere around $-100 \mathrm{~m}$ depth. An equivalent regional erosional truncation surface has also been recognised along the southern coast of the Black Sea (Algan et al., 2007; Demirbag et al., 1999; Gorur et al., 2001). A similar depth has also been deduced from a terrace on the northern shelf-edge (Major et al., 2002b).

Preservation of the sand dunes and the occurrence of small, buried incised valleys mark a rapid transgression during which ravinement processes related to the water level rise had no time to erode the seafloor significantly (Benan and Kocurek, 2000; Lericolais et al., 2004). Between 8.5 and $7.5 \mathrm{kyr}{ }^{14} \mathrm{C} \mathrm{BP}$, the present-day conditions of the surface waters of the Black Sea were established abruptly as a result of the rapid flooding of the Black Sea by Mediterranean waters, as shown by dinoflagellate cyst records (Hiscott et al., 2007; Marret et al., 2007; Popescu et al., 2004) and other data (Ryan et al., 2003; Ryan et al., 1997). Simultaneously, widespread sapropel deposition began both on the continental slope and in the deep basin. A sudden (within $<1000$ yrs) inflow of a very large volume of marine Mediterranean waters occurred, resulting in an abrupt increase in salinity to their present-day euxinic values (Popescu et al., 2004). Evidence for this inflow can also be found in the abrupt replacement of fresh to brackish species by marine 
species (Hiscott et al., 2007; Major et al., 2006; Major et al., 2002b; Marret et al., 2007; Popescu, 2004). Furthermore, hydraulic modelling shows that about 60,000 cubic metres of water per second must have flowed into the Black Sea basin after the Bosphorus sill was breached and that it would have taken at least 33 years to equalize water levels in the Black Sea and the Sea of Marmara (Siddall et al., 2004). Such a sudden flood would have preserved the lowstand markers on the north-western shelf of the Black Sea. From this work we can propose a specific water level fluctuation curve for the Black Sea which synthesises the results presented here (Figure 9).

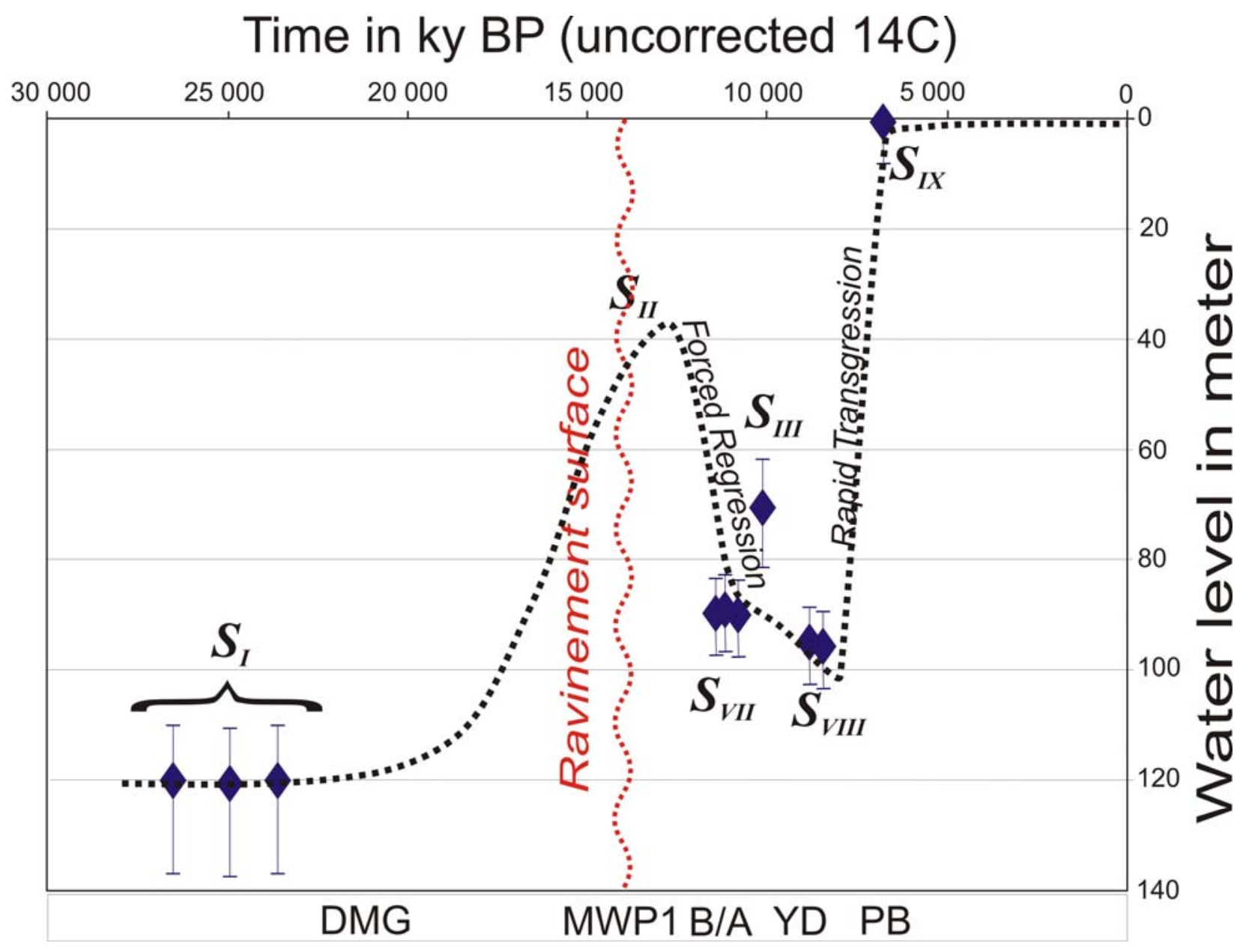

Figure 9: Water level fluctuation in the Black Sea since the Last Glacial maximum deduced from the observations recovered on the Northwestern Black Sea shelf. 


\section{Conclusions}

The transition of the Black Sea system from a lacustrine to a marine environment is perhaps one of the best records of climate change on the European continent. During the Last Glacial Maximum, 21,000 years ago, the Black Sea was probably a giant freshwater lake as proposed by (Arkhangelskiy and Strakhov, 1938) or at least a brackish enclosed basin. Its water level stood more than 120 m below than today's level. During the ASSEMBLAGE (EVK3-CT-2002-00090) European project, analysis of chirp high-resolution seismic reflection profiles together with piston core analyses from surveys realised on the Black Sea shelf provided new insight into recent sedimentation processes.

As the Black Sea was in very close vicinity to the Scandinavian-Russian ice cap, the melting water from the glaciers were supplied into the Black Sea through the major drainage system constituted by large European rivers (Danube, Dniepr, Dniestr and Bug). This water and sediment supply was correlated to the reddish layer deposits described in cores (Bahr et al., 2005; Major et al., 2002b; Strechie et al., 2002). The water brought to the Black Sea after the Melt Water Pulse 1A (MWP1A) at approximately 12,500 ${ }^{14} \mathrm{C}$ BP $(14,500$ Cal yrs BP; (Bard et al., 1990)) was supposed to be sufficiently important for the water level to rise between $40 \mathrm{~m}$ to $20 \mathrm{~m}$ below the present day sea level, where the Dreissena layers were deposited (Chepalyga, 1984). The $40 \mathrm{~m}$ isobath limit is interpreted from our records which are not exhaustive and the $20 \mathrm{~m}$ limit is certified by Valentina Yanko-Hombach (Yanko, 1990). This last value for the transgression upper limit would have brought the level of the Black Sea to a level higher than the Bosphorus sill and the possible inflow of marine species like Mediterranean dynoflagellate populations could be envisaged (Popescu, 2004). Palynological studies conducted on BlaSON cores 
(Popescu, 2004) show that during the Younger Dryas, a cool and drier climate prevailed. Northeastern rivers converged to the North Sea and to the Ancylus lake (Baltic Sea) (Jensen et al., 1999) resulting in reduced river input to the Black Sea and causing the shoreline to recede. These are consistent with some evaporative drawdown of the Black Sea and correlated to the evidence of an authigenic aragonite layer present in all the cores studied (Giunta et al., 2007; Jermannaud, 2004). This drawdown is also supported by the existence of the forced regression-like reflectors presented in this paper and recognised on the dune field mosaics and dated to this period. This lowered sea-level in the Black Sea persisted afterwards as implied by (1) the continuously dry climatic conditions in the region having started around 11 to $8 \mathrm{kyr}{ }^{14} \mathrm{C}$ BP (large percentages of herbs and steppe elements were described in the cores (Popescu, 2004)), (2) the dune formation between 10 and $8.5 \mathrm{kyr}{ }^{14} \mathrm{C}$ BP on the desiccated north-western Black Sea shelf at $-100 \mathrm{~m}$ depth, (3) the forced regression sequences dated from lacustrine species installed between 11 to $8.5 \mathrm{kyr}$ ${ }^{14} \mathrm{C}$ BP, (4) the wave cut terrace at $-100 \mathrm{~m}$ water depth posterior to these forced regression sequences . Numerous Russian authors also indicate a sea level lowstand at about $-90 \mathrm{~m}$ depth, based on the location of offshore sand ridges described at the shelf edge south of Crimea.

The sedimentary sequences in the Black Sea are strongly affected by sea level changes driven by global glaciation and deglaciation. The level of the Black Sea, to a certain extent, was controlled more by the regional climate than by global eustatic changes. During the Last Glacial Maximum, the Black Sea was an enclosed lake. The deglaciation raised the lake level but the Black Sea was still dependent on rapid climate change and between 11 to 8 kyr ${ }^{14} \mathrm{C}$ BP, the lake diminished to $-100 \mathrm{~m}$ depth and created a pronounced shoreline with a characteristic beach profile and a belt of coastal dunes. These coastal features as well as the incised anastomosed channel system were preserved on the shelf as the final transgression was fast enough to preserve them. 


\section{Acknowledgment}

Our research was supported by the French ministry of foreign affairs within the frame of a bi-lateral collaboration between France and Romania, and prolonged by a European project of the $5^{\text {th }}$ framework program called ASSEMBLAGE (EVK3-CT-2002-00090). Special acknowledgement goes to Nicolae Panin who started and supported the project. We also thank Eliane Le Drezen, Alain Normand for their work in multibeam data processing, Hervé Nouzé for seismic processing, the crew of the vessels "Le Suroît" (Ifremer) and "Marion Dufresne" (IPEV). Special thanks to Yvon Balut. A special "remerciement" goes to Timothy Garfield who edited this manuscript and for his helpful comments on sequence stratigraphy concepts. 


\section{References :}

Aksu, A.E. et al., 2002a. Persistent Holocene outflow from the Black Sea to the eastern Mediterranean contradicts Noah's Flood hypothesis. GSA Today, 12(5): 4-10.

Aksu, A.E., Hiscott, R.N., Yasar, D., Isler, F.I. and Marsh, S., 2002b. Seismic stratigraphy of Late Quaternary deposits from the southwestern Black Sea shelf: evidence for noncatastrophic variations in sea-level during the last 10000 yr. Marine Geology, 190(1-2): 61-94.

Algan, O. et al., 2007. Sea-level changes during the Late Pleistocene-Holocene on the southern shelves of the Black Sea. In: V. Yanko-Hombach, A.S. Gilbert, N. Panin and P.M. Dolukhanov (Editors), The Black Sea Flood Question: Changes in Coastline, Climate, and Human Settlement. Springer, New-York (USA), pp. 603-631.

Algan, O. et al., 2002. A high-resolution seismic study in Sakarya Delta and Submarine Canyon, southern Black Sea shelf. Continental Shelf Research, 22(10): 1511-1527.

Arkhangelskiy, A.D. and Strakhov, N.M., 1938. Geological structure and history of the evolution of the Black Sea. Izv. Akad. Nauk SSSR, 10: 3-104.

Arkhipov, S.A., Ehlers, J., Johnson, R.G. and Wright, H.E.J., 1995. Glacial drainage towards the Mediterranean during the middle and late Pleistocene. Boreas, 24(3): 196-206.

Aybulatov, N.A. and Shcherbakov, F.A., 1990. Avalanche sedimentation on the shelf of the Black Sea. International Geology Review, 32(2): 143-150.

Bahr, A., Arz, H.W., Lamy, F. and Wefer, G., 2006. Late glacial to Holocene paleoenvironmental evolution of the Black Sea, reconstructed with stable oxygen isotope records obtained on ostracod shells. Earth and Planetary Science Letters, 241(3-4): 863-875.

Bahr, A., Lamy, F., Arz, H., Kuhlmann, H. and Wefer, G., 2005. Late glacial to Holocene climate and sedimentation history in the NW Black Sea. Marine Geology, 214(4): 309-322.

Balabanov, I.P., 2007. Holocene sea-level changes of the Black Sea. In: V. Yanko-Hombach, A.S. Gilbert, N. Panin and P.M. Dolukhanov (Editors), The Black Sea Flood Question: Changes in Coastline, Climate, and Human Settlement. Springer, New-York (USA), pp. 603-631.

Ballard, R.D., Coleman, D.F. and Rosenberg, G., 2000. Further evidence of abrupt Holocene drowning of the Black Sea shelf. Marine Geology, 170(3-4): 253-261.

Bard, E., Hamelin, B., Fairbanks, R.G. and Zinder, A., 1990. A calibration of the 14C timescale over the past 30,000 years using mass spectrometric U-Th ages from Barbados corals. Nature, 345: 405-410.

Benan, C.A.O.A. and Kocurek, G., 2000. Catastrophic flooding of an aeolian dune field: Jurassic Entrada and Todilto Formations, Ghost Ranch, New Mexico, USA. Sedimentology, 47(6): 1069-1080.

Cagatay, M.N. et al., 2000. Late Glacial-Holocene palaeoceanography of the Sea of Marmara: timing of connections with the Mediterranean and the Black Seas. Marine Geology, 167: 191-206.

Calvert, S.E., 1990. Geochemistry and origin of the Holocene sapropel in the Black Sea. In: V. Ittekkot, S. Kempe, W. Michaelis and A. Spitzy (Editors), Facets of modern biogeochemistry. Springer-Verlag, Berlin, Federal Republic of Germany, pp. 326-352. 
Calvert, S.E. and Fontugne, M.R., 1987. Stable carbon isotopic evidence for the marine origin of the organic matter in the Holocene Black Sea sapropel. Chemical Geology, 66(3-4): 315322.

Chepalyga, A.L., 1984. Inland sea basins. In: A.A. Velichko, H.E.J. Wright and W. BarnoskyCathy (Editors), Late Quaternary environments of the Soviet Union. Univ. Minn. Press., Mineapolis, MN, United States, pp. 229-247.

Degens, E.T. and Ross, D.A., 1972. Chronology of the Black Sea over the last 25,000 years. Chem. Geol., 10: 1-16.

Demirbag, E., Gökasan, E., Oktay, F.Y., Simsek, M. and Yüce, H., 1999. The last sea level changes in the Black Sea: evidence from the seismic data. Marine Geology, 157(3-4): 249-265.

Deuser, W.G., 1972. Late-Pleistocene and Holocene history of the Black Sea as indicated by stable isotope studies. Jour. Geophys. Res., 77: 1071-1077.

Deuser, W.G., 1974. Evolution of anoxic conditions in the Black Sea during the Holocene. In: E.T. Degens and D.A. Ross (Editors), The Black Sea - Geology, Chemistry and Biology. Am. Assoc. Petrol. Geol, Tulsa (US), pp. 133-136.

Dimitrov, P.S., 1982. Radiocarbon datings of bottom sediments from the Bulgarian Black Sea Shelf. Bulg. Acad. Sci. Oceanology, 9: 45-53.

Evsylekov, Y.D. and Shimkus, K.M., 1995. Geomorphological and neotectonic development of outer part of continental margin to the south of Kerch Strait. Oceanology, 35: 623-628.

Fedorov, P.V., 1963. Stratigraphy of Quaternary sediments on the coast of the Crimea and Caucasus and some problems connected with the geological history of the Black Sea. Akad. Nauk SSSR Geol. Inst. Trudy, 88, 159 pp.

Fedorov, P.V., 1972. Postglacial transgression of the Black Sea. International Geology Review, 14(2): 160-164.

Fedorov, P.V., 1988. The problem of changes in the level of the Black Sea during the Pleistocene. International Geology Review, 30(6): 635-641.

Genov, I.D., 2004. Way and time of swell formation near the Bulgarian Black Sea shelf. Comptes Rendus de l'Academie Bulgare des Sciences, 57(6): 95-98.

Gillet, H., Lericolais, G., Rehault, J.-P. and Dinu, C., 2003. La stratigraphie oligo-miocene et la surface d'erosion messinienne en mer Noire, stratigraphie sismique haute resolution: The Oligo-Miocene stratigraphy and the Messinian erosional surface in Black Sea, highresolution seismic stratigraphy. Comptes Rendus Geosciences, 335(12): 907-916.

Giosan, L., 2007. V. Yanko-Hombach, A.S. Gilbert, N. Panin and P.M. Dolukhanov, Editors, The Black Sea Flood Question: Changes in Coastline, Climate and Human Settlement, Springer, Berlin (2007) ISBN 978-1-4020-4774-9 971pp., 246 illus. Quaternary Science Reviews, 26(13-14): 1897-1900.

Giunta, S., Morigi, C., Negri, A., Guichard, F. and Lericolais, G., 2007. Holocene biostratigraphy and paleoenvironmental changes in the Black Sea based on calcareous nannoplankton. Marine Micropaleontology, 63(1-2): 91-110.

Gorur, N. et al., 2001. Is the abrupt drowning of the Black Sea shelf at $7150 \mathrm{yr}$ BP; a myth? Marine Geology, 176(1-4): 65-73.

Guichard, F., Carey, S., Arthur, M.A., Sigurdsson, H. and Arnold, M., 1993. Tephra from the Minoan eruption of Santorini in sediments of the Black Sea. Nature, 363(17): 610-612.

Hiscott, R.N. et al., 2007. A gradual drowning of the southwestern Black Sea shelf: Evidence for a progressive rather than abrupt Holocene reconnection with the eastern Mediterranean Sea through the Marmara Sea Gateway. Quaternary International, 167-168: 19-34. 
Jensen, J.B., Bennike, O., Witkowski, A., Lemke, W. and Kuijpers, A., 1999. Early Holocene history of the southwestern Baltic Sea: The Ancylus Lake stage. Boreas, 28(4): 437-453.

Jermannaud, P., 2004. Etude sédimentologique et sismique des dépôts quaternaires de l'éventail profond du Danube. Master 2 Thesis, Université de Bordeaux 1, Bordeaux, 50 pp.

Jones, G.A. and Gagnon, A.R., 1994. Radiocarbon chronology of Black Sea sediments. Deep Sea Research 1, 41(3): 531-557.

Khrischev, K.G. and Georgiev, V.M., 1991. Regional washout on the Pleistocene-Holocene Boundary in the western Black-Sea depression. Comptes Rendus de l'Academie Bulgare des Sciences, 44(9): 69-71.

Kuprin, P.N., Scherbakov, F.A. and Morgunov, I.I., 1974. Correlation, age, and distribution of the postglacial continental terrace sediments of the Black Sea. Baltica, 5: 241-249.

Kwiecien, O. et al., 2006. Preliminary results on core MD04 2760 from the southwestern Black Sea. In: E.G.U. 2006 (Editor), European Geosciences Union 2006. Geophysical Research Abstracts, Vienna (Ost), pp. 06947.

Lane-Serff, G.F., Rohling, E.J., Bryden, H.L. and Charnock, H., 1997. Postglacial connection of the Black Sea to the Mediterranean and its relation to the timing of sapropel formation. Paleoceanography, 12(2): 169-174.

Lericolais, G., Allenou, J.-P., Berné, S. and Morvan, P., 1990. A new system for acquisition and processing of very high-resolution seismic reflection data. Geophysics, 55(8): 1036-1046.

Lericolais, G., Berné, S. and Féniès, H., 2001. Seaward pinching out and internal stratigraphy of the Gironde incised valley on the shelf (Bay of Biscay). Marine Geology, 175((1-4)): 183197.

Lericolais, G. et al., 2004. Rapid transgressions into semi-enclosed basins since the Last Glacial Maximum. In: IGC-IUGS-UNESCO (Editor), 32nd IGC Florence 2004, Florence, pp. Session 249: T05.03 - Continental shelves during the last glacial cycle 249-4.

Lericolais, G., Maltese, L. and Assemblage partners, 2005. Assemblage deliverable 12: Lithological logs, digital photographs, gamma and magnetic susceptibility logs, European Community, Energy, Environment and Sustainable Development, Brest.

Lericolais, G., Popescu, I., Guichard, F. and Popescu, S.M., 2007a. A Black Sea lowstand at 8500 yr B.P. indicated by a relict coastal dune system at a depth of $90 \mathrm{~m}$ below sea level. In: J. Harff, W.W. Hay and D.M. Tetzlaff (Editors), Coastline Changes: Interrelation of Climate and Geological Processes. GSA Books; Allen Press, Inc., Special Paper 426, pp. 171-188.

Lericolais, G., Popescu, I., Guichard, F., Popescu, S.M. and Manolakakis, L., 2007b. Water-level fluctuations in the Black Sea since the Last Glacial Maximum. In: V. Yanko-Hombach, A.S. Gilbert, N. Panin and P.M. Dolukhanov (Editors), The Black Sea Flood Question: Changes in Coastline, Climate, and Human Settlement, pp. 437-452.

Lericolais, G., Popescu, I., Panin, N., Ryan, W.B.F. and Guichard, F., 2003. Last Rapid Flooding in the Black-sea. In: S. Uscinowicz and J. Zachowicz (Editors), Rapid transgressions into semi-enclosed basins - IGCP 464. Polish Geological Institute, Gdansk, pp. 39.

Lericolais, G. et al., 2006. High frequency sea level fluctuations recorded in the Black Sea since the LGM. In: G. Camoin, D. A., C. Fulthorpe and K. Miller (Editors), Sealaix'O6 International Symposium "Sea Level Changes : Records, Processes and Modelling", Giens (France), pp. 132-133.

Major, C., Goldstein, S.L., Ryan, W., Piotrowski, A. and Lericolais, G., 2002a. Climate change in the black sea region through termination $\mathrm{I}$ from $\mathrm{Sr}$ and $\mathrm{O}$ isotopes. Geochimica $\mathrm{Et}$ Cosmochimica Acta, 66(15A): A476-A476. 
Major, C.O. et al., 2006. The co-evolution of Black Sea level and composition through the last deglaciation and its paleoclimatic significance. Quaternary Science Reviews, 25(17-18): 2031-2047.

Major, C.O., Ryan, W.B.F., Lericolais, G. and Hajdas, I., 2002b. Constraints on Black Sea outflow to the Sea of Marmara during the last glacial-interglacial transition. Marine Geology, 190(1-2): 19-34.

Manheim, F.T. and Chan, K.M., 1975. Interstitial Waters of Black Sea Sediments; New Data and Review.; The Black Sea; Geology, Chemistry, and Biology; Water. Memoir - American Association of Petroleum Geologists, 20: 155-180.

Marret, F., Mudie, P., Aksu, A. and Hiscott, R.N., 2007. A Holocene dinocyst record of a twostep transformation of the Neoeuxinian brackish water lake into the Black Sea. Quaternary International, In Press.

Mitchum, R.M., Vail, P.R. and Sangree, J.B., 1977. Stratigraphic Interpretation of Seismic Reflection Patterns in Depositional Sequences. In: C.E. Payton (Editor), Seismic stratigraphy - Application to hydrocarbon exploration. Amer. Assoc. Pet. Geol. Bull. AAPG, Tulsa, Oklahoma, pp. 117-133.

Muratov, V.M., Ostrovskiy, A.B. and Fridenberg, E.O., 1974. Quaternary stratigraphy and palaeogeography on the Black Sea coast of Western Caucasus. Boreas, 3(2): Pages 49-60.

Neprochnov, Y.P., 1980. Geologicheskaya istoriya Chernogo morya po rezul'tatam glubokovodnogo bureniya - (Translated Title: The geologic history of the Black Sea from the results of deep-sea drilling). Nauka Press, Moscow, USSR, 212 pp.

Nevesskaja, L.A. and Nevesskiy, Y.N., 1961. Relationship between the Karangat and Neoeuxine beds in littoral regions of Black Sea. Akad. Nauyk SSSR Doklady, 137(4): 934-937.

Nouzé, H., 1993. Intégration de nouveaux modules de traitements de sismique très haute résolution dans SITHERE. 9305, ENSPM, Diplôme Ingénieur.

Okyar, M., Ediger, V. and Ergin, M., 1994. Seismic stratigraphy of the southeastern Black Sea shelf from high-resolution seismic records. Marine Geology, 121(3-4): Pages 213-230.

Ostrovskiy, A.B. et al., 1977a. New data on the paleohydrological regime of the Black Sea in the Upper Pleistocene and Holocene. In: P.A. Kaplin and F.A. Shcherbakov (Editors), Paleogeography and Deposits of the Pleistocene of the Southern Seas of the USSR. Nauka Press, Moscow, pp. 131-141.

Ostrovskiy, A.B., Sccheglo, A.P., Arslanov, S.A. and Shchelinskiy, V.Y., 1977b. New data on the stratigraphy and geochronology of Pleistocene marine terraces of the Black Sea coast, Caucasus, and Kerch-Taman region. In: P.A. Kaplin and F.A. Shcherbakov (Editors), Paleogeography and Deposits of the Pleistocene of the Southern seas of the USRR. Nauka-Press, Moskow, pp. 61-99.

Panin, N. and Popescu, I., 2007. The northwestern Black Bea: climatic and sea level changes in the Upper Quaternary. In: V. Yanko-Hombach, A.S. Gilbert, N. Panin and P.M. Dolukhanov (Editors), The Black Sea Flood Question: Changes in Coastline, Climate, and Human Settlement, New-York, pp. 387-404.

Popescu, I. et al., 2004. The Danube Submarine Canyon (Black Sea): morphology and sedimentary processes. Marine Geol., 206(1-4): 249-265.

Popescu, S.M., 2004. Sea-level changes in the Black Sea region since 14 ka BP. In: IGC-IUGSUNESCO (Editor), 32nd IGC Florence 2004, Florence, pp. Session : T34.02 - Sea-level change since the last glacial maximum. 
Popescu, S.M., Head, M. and Lericolais, G., 2003. Holocene Black Sea environments according to palynology. In: G.S.o. America (Editor), GSA Annual Meeting. GSA Abstracts with Programs, Seattle, Wa, pp. 462.

Popp, N., 1969. The Quaternary deposits in the Danube valley in Romania and the paleo-Danube river bed. 12(1-2): 67-72.

Ross, D.A., 1971. The Red and the Black Seas. American Scientist, 59(July/ August): 420-424.

Ross, D.A. (Editor), 1978. Summary of results of Black Sea Drilling. Initial Rep. Deep Sea Drill. Proj., 42. US Govt. Print. Office, Washington, DC, 1149-1178 pp.

Ross, D.A., Degens E. T. and MacIlvaine, J., 1970. Black Sea: recent sedimentary history. Science, 170(9 October): 163-165.

Ross, D.A. and Degens, E.T., 1974. Recent sediments of the Black Sea. In: E.T. Degens and D.A. Ross (Editors), The Black Sea - Geology, Chemistry and Biology. Amer. Assoc. Petrol. Geol., Tulsa, pp. 183-199.

Ryan, W.B.F., Major, C.O., Lericolais, G. and Goldstein, S.L., 2003. Catastrophic Flooding of the Black Sea. Annu. Rev. Earth Planet. Sci., 31(1): 525-554.

Ryan, W.B.F. et al., 1997. An abrupt drowning of the Black Sea shelf. Marine Geology, 138(12): 119-126.

Shcherbakov, F.A. and Babak, Y.V., 1979. Stratigraphic subdivision of the Neoeuxinian deposits in the Black Sea. Oceanology, 19(3): 298-300.

Shcherbakov, F.A., Chistyakov, A.A. and Kuprin, P.N., 1980. Modern structure of the northern side of the Black Sea basin. Moscow University Geology Bulletin, 35(4): 21-27.

Shcherbakov, F.A. et al., 1978. Sedimentation on the Continental Shelf of the Black Sea. Nauka Press, Moscow, 211 pp.

Shimkus, K.M., Evsyukov, Y.D. and Solovjeva, R.N., 1980. Submarine terraces of the lower shelf zone and their nature. In: Y.P. Malovitsky and K.M. Shimkus (Editors), Geological and Geophysical Studies of the Pre-Oceanic Zone. P.P. Shirshov Inst. of Oceanology Acad. Sci. USSR,, Moscow, pp. 81-92.

Shimkus, K.M., Komarov, A.V., Khrischov, K.D. and Zveryaka, A.F., 1987. Lithological constitution and areal distribution of the Upper Quaternary deposits within the Danube fan. In: A.G. Rozonov (Editor), Sedimentation in the River Mouth Areas of the Western Black Sea: Lithology and Geochemistry. Acad. Sci. USSR, Inst. Ocean., Moscow, pp. 2833.

Shopov, V., Chochov, S. and Georgiev, V., 1986. Lithostratigraphy of Upper Quaternary sediments from the northwestern Black Sea shelf between the parallels of the Cape Emine and Danube River mouth. Geologica Balcanica, 16(6): 99-112.

Shuisky, Y.D., 1986. Studies of Aeolian Processes on Seashores of the Soviet Union. Geografiska Annaler. Series A, Physical Geography, 68(1/2 ): 33-40.

Siani, G. et al., 2000. Radiocarbon Reservoir Ages in the Mediterranean Sea and Black Sea. Radiocarbon, 42(2): 271-280.

Siddall, M., Pratt, L.J., Helfrich, K.R. and Giosan, L., 2004. Testing the physical oceanographic implications of the suggested sudden Black Sea infill 8400 years ago. Paleoceanography, 19(PA1024): 1-11.

Sperling, M. et al., 2003. Black Sea impact on the formation of eastern Mediterranean sapropel S1? Evidence from the Marmara Sea. Palaeogeography, Palaeoclimatology, Palaeoecology, 190: 9-21. 
Strechie, C. et al., 2002. Magnetic minerals as indicators of major environmental change in holocene black sea sediments: preliminary results. Physics and Chemistry of the Earth, Parts A/B/C, 27(25-31): 1363-1370.

Talling, P.J., 2000. Self-organization of river networks to threshold states. Water Resources Research, 36(4): Pages 1119-1128.

Wall, D. and Dale, B., 1974. Dinoflagellates in the late Quaternary deep-water sediments of the Black Sea. In: E.T. Degens and D.A. Ross (Editors), The Black Sea - Geology, Chemistry and Biology. Amer. Assoc. Petrol. Geol., Tulsa, pp. 364-380.

Wescott, W.A., 1993. Geomorphic thresholds and complex response of fluvial systems-Some implications for sequence stratigraphy. American Association of Petroleum Geologists, Bulletin, 77(7): 1208-1218.

Wong, H.K., Lericolais, G., Gillet, H. and Assemblage partners, 2005. Assemblage deliverable 10: Interpretation of seismic profiles and the resulting sequence stratigraphy models, European Community, Energy, Environment and Sustainable Development, Brest.

Yanko-Hombach, V., Gilbert, A.S. and Dolukhanov, P., 2007a. Controversy over the great flood hypotheses in the Black Sea in light of geological, paleontological, and archaeological evidence. Quaternary International, 167-168: 91-113.

Yanko-Hombach, V., Gilbert, A.S., Panin, N. and Dolukhanov, P.M., 2007b. The Black Sea Flood Question. Changes in Coastline, Climate and Human Settlement. Springer, NewYork (USA), 975 p. 246 illus. pp.

Yanko, V., 1990. Stratigraphy and Paleogeography of Marine Pleistocene and Holocene Deposits of the Southern Seas of the USSR. Mem. Soc. Geol. Ital., 44: 167-187. 